\title{
Juan García Ponce: avatares del deseo
}

\author{
Juan Antonio Rosado Z. \\ Facultad de Filosofía y Letras \\ Universidad Nacional Autónoma de México
}

Tanto la crítica en torno a la obra del escritor yucateco Juan García Ponce (1932-2003) como el autor mismo coinciden en aplicar a su extensa obra el calificativo de "intimista", una obra ajena — en general- a los espacios exteriores, a las masas y a lo que tenga que ver con la política y la sociedad. En una entrevista, el narrador señala: "Soy un autor de lugares privados, de interiores" (Vallarino: 1). Si excluimos sus novelas La invitación (1972) y Crónica de la intervención (1982), la mayor parte de las atmósferas y situaciones narrativas se desarrollan en espacios interiores, en la intimidad propicia para el desarrollo del amor y del erotismo. Las dos mencionadas novelas son, de hecho, las únicas que contienen un alto grado de conciencia política y un cierto desarrollo del tema social, al incluir — sin hacer explícitos ni el espacio ni las fechas reales o históricas - el movimiento estudiantil de 1968 y, en el caso de Crónica de la intervención (capítulo XXIX), también la masacre de los estudiantes por el ejército, el 2 de octubre de ese año. El presidente Gustavo Díaz Ordaz, cuyo nombre no se menciona, es descrito en el capítulo XXVIII: "el rostro de la Revolución era el de un abogaducho con gruesos lentes que parecía tener hacia afuera su propia calavera mostrando una inconcebiblemente protuberante hilera de dientes aun sin hacer ningún gesto" (García Ponce 1992, v. II: 374). Luego se nos habla de su trayectoria política, sumergida en la adulación hacia su partido. El narrador muestra su antipatía por Díaz Ordaz al representarlo como un "mandril con lentes de miope, la calavera hacia afuera y el cuerpo enclenque con el pecho atravesado por la banda presidencial" y como un "siniestro 
mandril" cuyo "pseudoinforme" a la nación encubría una serie de amenazas.

En cuanto a La invitación, su tema fundamental —más que el político- es la identidad, tema que aparece prácticamente en toda la obra de este escritor. Aun así, son claras las fuerzas irreconciliables que suelen enfrentarse bajo las formas de política como conflicto y política como orden. El orden y el placer son encontrados —efímeramente- por el protagonista $\mathrm{R}$ en Beatrice y en la intimidad compartida con ella. El conflicto, marcado por las sirenas y por una experiencia autobiográfica a la que me referiré más adelante, es rechazado por $\mathrm{R}$ porque pone trabas a la realización del amor.

No obstante, a pesar de que, como narrador, García Ponce haya hecho explícitas sus preocupaciones políticas sólo en dos novelas, se trata — si tomamos la palabra "política" en un sentido más amplio que el referido a las instituciones gubernamentales o al poder que de ellas emanan- de un autor eminentemente político, que propone una relación positiva (sin alterar el orden externo) y desinhibida entre los seres humanos, quienes deben desplegar inocentemente su sexualidad. Asimismo — como lo comprobaré en este ensayo- propone un tipo de comunidad basada en el mutuo respeto (nadie fuerza la voluntad de nadie), en la tolerancia y en la consecución del placer, cuyos ejes son el arte y la figura femenina. Para expresarlo con una fórmula de Henry Miller, el mundo de García Ponce es una especie de "mundo ovárico". Ciertamente, el tipo de comunidad propuesta implícitamente por el autor no deja de ser utópica, aunque posible en el reino de la imaginación. Como promotor de un idealismo esteticista, ${ }^{1}$ García Ponce — un ateo cuya "religión" es el Arte — no niega la posibilidad de que la vida imite al arte: "Cuando el arte imita al arte la imitación nunca es exacta, ocurre lo mismo que cuando el arte imita a la vida y muy probablemente cuando la vida imita al arte" (García Ponce 1982b: 41). El autor apuesta por el arte y por la vida.

Para Michelangelo Bovero, coexisten dos ideas o nociones generales de política que al parecer están a menudo mezcladas o confundidas, y cada una de ellas corresponde a una manera diferente de conjugar el poder y la política. Estas nociones son, por un lado, la política como

\footnotetext{
${ }^{1}$ A este respecto, véase mi ensayo "El engaño colorido: Juan García Ponce, sor Juana Inés de la Cruz y José Vasconcelos”, en El engaño colorido (2003: 121-134).
} 
"contraposición" o conflicto (por ejemplo, la imposición del dominio del más fuerte, así como todo tipo de lucha o dominación) y, por otro, la política como "composición" (la paz, "la salida del estado de guerra"). El origen del nombre "política", de polis, aristotélicamente la comunidad de ciudadanos, hace pensar a Bovero que la política está más bien ligada a la segunda noción (Bovero: 37-39). Al respecto, recordemos a Aristóteles: "Toda ciudad se ofrece a nuestros ojos como una comunidad y toda comunidad se constituye a su vez en vista de algún bien (ya que todos hacen cuanto hacen en vista de lo que estiman ser un bien)" (Aristóteles: 157). La posición de este ensayo es que García Ponce, al privilegiar el estado de juego implícito en el arte, rechaza la violencia y la política como conflicto, y apuesta por un vitalismo energético y positivo, así como por un tipo de relación política que no atente contra el orden exterior ni contra la comunidad. Para comprobarlo, comenzaré por exponer algunos elementos biográficos para centrarme después en la figura femenina que aparece en su obra: en el autor como fenomenólogo de la Mujer y en la Mujer como metáfora del Arte y de la Vida. También contrastaré a García Ponce con el Marqués de Sade, con el objeto de percibir dos ideas radicalmente opuestas de relación política.

No ahondaré en la vida de García Ponce porque, finalmente, su obra es lo que nos interesa. Él mismo advierte: "El escritor no existe, existen sus libros" (Poniatowska: 9), y "la creación crea al creador en el mismo sentido que él crea la creación" (Hahn: 15). La creación es una fuerza que a menudo desborda al autor, quien se pierde en su propia obra y es ésta la que adquiere realidad, vida. La literatura es entonces una voz sin dueño por ser producto de nuestro yo profundo. Para García Ponce, la persona no es sino depositaria de una vocación —en su caso, la literaria—, y es la vocación la que merece celebrarse.

De hecho, hay un aspecto que ha llamado la atención en su biografía: la pasión y disciplina con que asumió la vocación de escritor: "vivir y escribir son la misma cosa. Mi vida ha ido haciendo mis libros; mis libros han ido haciendo mi vida" (García Ponce 1989: 44). Cuando perdió la fe en Dios, nunca abandonó cierto espíritu religioso "que está dirigido hacia otro lado y se manifiesta de una manera distinta" (García Ponce 1966: 37). Esa manera es justamente el estado de juego implícito en el arte. Este creador ha sido fiel a su vocación incluso en 
los momentos más dramáticos, cuando contrajo la esclerosis múltiple que paralizó su cuerpo, aunque no su vitalidad.

Durante el movimiento estudiantil de 1968, García Ponce colaboró en el Comité Olímpico Mexicano. En Trazos (1974), reproduce tres textos sobre el 68: "La nacionalidad de las ideas", "El subreino de la ilegalidad" y "El escritor como ausente". En el segundo, del 18 de septiembre de ese año, denuncia el imperio de la ilegalidad que rige al país. La institucionalización de la violencia, además de trivializarla, de volverla cotidiana, la acrecienta a medida que el gobierno pierde legitimidad. A menor legitimidad, mayor violencia. Eso ocurrió en 1968, y García Ponce lo denunció.

En Crónica de la intervención se menciona que Anselmo, "con una hermética ironía", ha escrito y publicado un artículo sobre la "nacionalidad de las ideas" y más adelante otro en el que "comentaba la toma de la Universidad en términos quizás demasiado irónicos, pero también violentos e irrespetuosos". Las características de esos artículos, como lo ha notado Juan Pellicer, corresponden a las de los publicados por García Ponce (Pellicer: 180). Ambos asumen una posición política contra el autoritarismo y la falta de legalidad. En esta época unos policías detuvieron al escritor a las afueras del periódico Excélsior porque lo "confundieron" con Marcelino Perelló, uno de los líderes del Movimiento Estudiantil, "que andaba en silla de ruedas también - comenta García Ponce-, y un policía me puso la pistola en el estómago. Me dijo: ¡Párese hijo de la chingada! Le respondí: me encantaría, pero no puedo" (Flores Aguilar: 7), experiencia que, con variantes, narra en La invitación. Es también sintomático que en el tercer texto mencionado afirme: "Yo preferí vivir en el espacio de la imaginación. Las obsesiones eran más fuertes que los ofrecimientos del mundo", lo que significa que su compromiso es con la literatura: "a mí me importa la sociedad un diablo. Jamás pienso siquiera en ningún lector en el momento de escribir [...] Yo soy mi propio lector, y ese solo lector representa a todos los lectores" (Asa: 5). ${ }^{2}$ Con esto vuelvo a una idea expresada anteriormente: lo importante es la obra. En este caso, una obra marcada por la intimidad y por la presencia ubicua de la mujer, el centro rector de las tramas.

\footnotetext{
${ }^{2}$ En otro lugar afirma: "La escritura no es un acto de soledad. Aspira a dirigirse aunque sea a un lector porque ese lector representa a todos los lectores" (Espinosa: 45).
} 
¿Cuál es la imagen de la Mujer que nos presenta Juan García Ponce? Prácticamente todas las situaciones narrativas giran en torno del yo (u otro, según la perspectiva) femenino. Fascinado por la mujer, el autor de Crónica de la intervención ha recreado una imagen de ella en la que entra en juego todo un vocabulario y un discurso generado por la mirada y el deseo, por una contemplación llena de plenitud. En Trópico de capricornio, cuando Henry Miller alude al Mundo Nuevo que estaba describiendo, el mundo del sexo, el "mundo ovárico, todavía escondido en las trompas de Falopio", afirma que cualquier hombre primitivo lo habría entendido. El Mundo ovárico es una utopía feminista en el sentido que García Ponce le confiere a esa palabra cuando, en una entrevista, se considera "feminista" al referirse al personaje predominantemente femenino de su narrativa (Albarrán / Gutiérrez: 16).

Pero el despliegue de la feminidad se lleva a cabo mediante un ritual propiciatorio. En Pasado presente (1995) se dice que "Todas las mujeres quieren exhibirse, es una parte de lo femenino, la cuestión es tener la pareja adecuada para ello y Xavier hasta estaba dispuesto a hacerse responsable de los actos de Geneviève" (García Ponce 1995a: 325). En otras palabras, hay mujeres reprimidas, que no exhiben su feminidad o que simplemente no se exhiben, y otras que sí. Son a estas últimas a las que incluyo en la categoría Mujer (con mayúscula), intuición de una esencia en la fenomenología de García Ponce, ya que los rasgos de esta especie de "reducción fenomenológica" pueden ser percibidos en una serie de mujeres. Entre los rasgos de la Mujer, encuentro la apertura y la disponibilidad, que incluye el goce exhibicionista, y la objetivación, que incluye la relación sumisión-obediencia, así como la vía hacia la impersonalidad; todo esto desde la plenitud que implica la inocencia o carencia de culpa, que es a la vez comienzo y resultado, sin importar las contradicciones, dudas y hasta vergüenzas que pudieron manifestarse entre ese inicio y su término, que, al volverse de nuevo inicio, repite el ciclo del Deseo, con la movilidad propiciada por la dialéctica de los contrarios. La mujer individual, con nombre propio - llámese Mariana, Paloma, Inmaculada, Alma, Claudia, Nicole, Beatrice, Geneviève... — , se convierte en Mujer (impersonal): "convertirse en objeto es renunciar a la identidad para ser como la vida: sin dueño. La mujer que es sólo su cuerpo no es de nadie" (García Ponce 1982a: 110); es decir, es de todos, como el Arte. 
En la constante transgresión de las convenciones sociales y del prurito judeocristiano por la reproducción, la Mujer, cuya obediencia y sumisión es paralela y proporcional a su disponibilidad sexual, representa el papel preponderante. Muchos son los personajes femeninos de García Ponce que demuestran dicha disponibilidad. Estas mujeres constituyen el centro de gravedad del mundo fenomenológico del narrador.

Ahora bien, el gesto propiciatorio de la manifestación de la Mujer es a menudo iniciado por el varón gracias a la mirada. Por ello, la $\mathrm{Mu}-$ jer tiene siempre un papel dinámico, cambiante, mientras que el varón, con excepción del protagonista de El nombre olvidado, es sobre todo estático. La mujer es deseada porque otros la muestran, la revelan, pero también porque se muestra deseable, entregada a la mirada del otro. "Si alguien me viera, me gustaría gustarle", dice Alma en la novela El gato (1974). Ella experimenta una voluntad de exponer su cuerpo, voluntad motivada por la presencia de una figura masculina. El hombre incluso llega a encontrar en la mirada de los demás, dirigida a la Mujer, su propia admiración y hasta el amor como deseo por ella. Mujer y Arte son siempre mirados por otro. El hombre incita a la mujer (individual) a convertirse en Mujer (objeto, finalidad). La Mujer es entonces una creación del Deseo. En el cuento "Rito" se afirma que Liliana "es siempre la misma porque ha elegido no ser nadie más que aquella en que la convierten" (García Ponce 1997: 308). La narración, de hecho, finaliza con estas palabras de Liliana: “¿Qué humillación! —comenta— ¡Todo el mundo que quiere me coge!” (ibid., 334). En La invitación leemos que durante el día la única realidad de Beatrice era la creada por el deseo de R.

Para comprender por qué Arte y Mujer están estrechamente relacionados en García Ponce y por qué, en cierto sentido, la Mujer es metáfora del Arte y de la Vida, debe tomarse en cuenta el sentido del vocablo "fenómeno": "lo que aparece", la "mera representación". Esto, de acuerdo con la postura que tomemos, puede contraponerse al ser verdadero y encubrirlo, pero también puede constituir el camino hacia lo verdadero en tanto que las verdades se manifiestan a través de las apariencias. Para que algo se revele, requiere ser iluminado, pero tal apariencia puede ser engañosa. El fenómeno es también producto de la intuición: un objeto aparente. Para García Ponce, la verdad en el arte se mezcla con la mentira, la luz con la sombra, lo que implica que 
al arte no le interesa la verdad, sino la apariencia, la belleza del fenómeno. A la fenomenología implícita en la narrativa no le interesa distinguir entre verdad y apariencia, sino contemplar la apariencia de verdad. La fenomenología en este autor se limita a describir las apariencias para que éstas sean contempladas y así convencer, pero tales descripciones son combinadas con la narración y la reflexión dialéctica. Más que un método, la fenomenología es, en García Ponce, una manera de ver, un acto voyeurista, pues su escritura no implica un "método" filosófico: no desea racionalizar ni homogeneizar al universo. La ambigüedad y la transgresión no permitirían tal tentativa.

García Ponce coincide con Georges Bataille en su visión del erotismo como algo heterogéneo. Lo Absoluto o la "totalidad" hegeliana de la $\mathrm{Fe}$ nomenología del Espíritu es homogeneizante porque pretende sistematizar la realidad. Para Hegel, la "fenomenología del Espíritu” muestra la sucesión de fenómenos de la conciencia para así llegar al "Saber Absoluto". El espíritu en Hegel es un universal que se va completando. Hegel procura introducirse en un sistema total de la ciencia presentando su devenir. La filosofía y, ante todo, la ética anti-hegeliana de Emmanuel Levinas ya implica el "cara-a-cara" como una relación sin violencia, donde se propone que la totalidad hegeliana es alienante y donde no se asume la negación del objeto. Totalidad e infinito, de Levinas, no está apoyada en la razón universal ni en la supuesta objetividad; más bien critica la filosofía como supremacía de lo uno sobre la pluralidad; reflexiona sobre la exterioridad, sobre el otro en tanto que escapa de la totalidad. Ni Bataille ni García Ponce aceptan la homogeneidad del sistema. No obstante, en García Ponce podemos descubrir una lógica de acumulación de proposiciones propia de un discurso filosófico de carácter dialéctico. No existe, como en el Bataille de la experiencia ateológica, una pretensión de anular el encadenamiento proposicional. Tal discursividad desemboca en el orden del erotismo como transgresión, en la representación que lo muestra en su desarrollo como fenómeno heterogéneo. A diferencia de Bataille, puede afirmarse que en García Ponce el carácter dionisiaco y vitalista del contenido que emana del lenguaje, se combina con una prosa sintácticamente pulcra, organizada, clara, racional, apolínea en el sentido de que no llega — como Henry Miller- a un extremo lirismo, sino que se mantiene en la mesura y hasta frialdad de una forma en que la descripción y los conceptos no pierden la sobriedad ni siquiera al representar las situaciones menos sobrias. 
García Ponce articula un discurso lúcido, congruente al encadenar su pensamiento, si bien éste se convierte en una complacencia "perversa", lúdica, carente de un objetivo moral, filosófico, social, metafísico o teológico. La literatura es el espacio donde conviven cuerpo y espíritu, y esta dialéctica se manifiesta en el lenguaje. Si entendemos "espíritu" como el nous griego es entonces lo "intelectual" lo que contiene la razón, un principio pensante, opuesto a la materia y que trasciende lo orgánico y el tiempo. Pero en García Ponce, que parte de la muerte de Dios y de una postura ajena al logocentrismo, el espíritu ha perdido su centro y, por ello, se encuentra en una "errancia sin fin". Entonces no existe la verdad, sino que cada quien la descubre en sí mismo: "el mundo es espíritu, la verdad está en nosotros y el gran artista es aquel que, al encontrarla en sí mismo, la reconoce en todas las cosas y es capaz de comunicárnosla" (García Ponce 1997b: 89), posición que coincide con la filosofía de los jainas de la antigua India, para quienes cada quien tiene una perspectiva distinta de la verdad y así la verdad se pluraliza, se convierte en verdades. Pero en García Ponce, a diferencia de los jainas, no se trata de llegar a la aniquilación ontológica con la anulación de la trasmigración del alma (samsara), sino a la consecución de la representación de nuestra verdad en el arte, porque es allí —en la representación artística — donde habla el espíritu a la vida, al reino del más acá, porque de ese reino toma sus materias. El espíritu se manifiesta en la literatura a través del lenguaje, contrapuesto a la vida, y en el erotismo a través de los cuerpos; pero este erotismo debe ser transgresor en cuanto a sus fines, es decir, improductivo: "La esterilidad del amor homosexual —afirma García Ponce en un ensayo sobre Proust-, de las pasiones perversas, sólo las hace más espirituales en su gratuidad, en su carácter ajeno a todo movimiento utilitario" (García Ponce 1982a: 306), y en el cuento "Rito" leemos: "La natural fuerza de la sensualidad se pone al servicio de la perversión que la deforma y negando toda naturalidad entra al campo del espíritu cuando lo que se muestra es el poder de seducción de la carne" (García Ponce 1997a: 322).

Es importante la dialéctica materia-espíritu porque el pensamiento de García Ponce es fenomenológico y dialéctico; nos remite a una totalidad paradójicamente ilimitada y asistemática; todo es parte de la continuidad del movimiento: "Ese movimiento expulsa de su seno a la palabra 'uno"' (García Ponce 1992, v. I: 98), lo que hace que todo 
subsista en la pluralidad. Sin embargo, por su continua transformación, con tal fenomenología accedemos a lo que yo calificaría como seudo-ontología. La función seudo-ontológica de la transgresión en el arte hace que al nombrar el ser para desbordarlo al introducirlo en la carne, se revele a la vez su presencia (en la Mujer).

Ciertamente, en García Ponce no existe un sistema filosófico cerrado, pero tal ausencia es rasgo general de la literatura, ya que ésta, a diferencia de la filosofía como sistema, no pretende formular un saber que explique y fundamente lo real. El sistema de razones en el escritor yucateco nace de las emociones que al repetirse se examinan, y la dialéctica razón-irracionalidad anula toda posibilidad de sistematización. Una de las pruebas de esto sería confrontar el discurso racional del sicoanalista con el del sacerdote herético o con el de Esteban en Crónica de la intervención. El discurso del doctor Raygadas inmiscuye la lógica y busca encerrar a María Inés en un razonamiento freudiano, sicoanalítico. Pero, como afirma el escritor al referirse a Klossowski, "la respuesta no está en la lógica, sino en el contenido de las intensidades" (García Ponce 1975: 63), ya que no hay principio ordenador omnipresente —ni Dios ni Freud-y si se vislumbra es transgredido en el arte. La lógica, la razón sólo pueden cuestionar y, si acaso, explicar de un modo perspectivista. El movimiento vital no encuentra, sin embargo, su orden en los cuestionamientos ni en explicaciones. El arte constituye otro orden; la transgresión encamina al supuesto "desorden" hacia la consecución de otro orden, un orden intuido en las obsesiones, en la frecuencia ritual de las situaciones.

Mariana es oleaje sin fin y vive - a los ojos del sacerdote- en un constante movimiento interno que la desplaza de ser María Inés a ser Mariana, una y distinta, dos mujeres acaso irreconciliables, pero también —en la fantasía - una individualidad contradictoria, una dualidad, una interrogante sobre la identidad, un "desdoblamiento" asociado con la locura y lo sobrenatural. El lector que ha leído la obra sabe que son dos mujeres cuya apariencia es idéntica. Algo fundamental para el escritor es resaltar el carácter polisémico y asistemático de la creación, donde los elementos se nieguen y afirmen, donde la transgresión implique un orden y el orden requiera su transgresión.

El movimiento no existiría sin la dialéctica de la afirmación y la negación. Un antiguo himno filosófico de la India (Rig Veda X, 129) que vincula al Deseo con la Idea, motor de las acciones que se dirigen 
a su contrario, afirma que "Buscando dentro de sí mismos los sabios / encontraron en el no-ser el vínculo con el ser". Mil años antes de Heráclito, este himno expresa que en toda unidad de contrarios existe la contradicción ser-no-ser o afirmación-negación — para los chinos, yin y yang, que también es lo femenino y lo masculino - con la que intuimos la totalidad, aunque una totalidad que no admite lo cerrado del sistema, sino el cambio: "Todos somos otro del que somos y cargamos con nosotros mismos" (García Ponce 1992 v. II: 126). Mariana es negación de María Inés y después María Inés desea acercarse a Mariana. El deseo nos une con el contrario para establecer la suma y aspirar a lo Absoluto, un Absoluto esencialmente abierto y - si es posible decirlo- en puntos suspensivos, que nos otorga lo que yo llamaría una sensación de lo inconcluso porque no se cierra con la aniquilación.

En García Ponce, la aspiración o deseo de Absoluto parte de la fenomenología de la Mujer o conjunto de apariencias que propicia el otro femenino, representado por algunas mujeres y descontinuado por otras. Mariana, Paloma, Inmaculada... son la afirmación de ese yo que se vuelve otro, de ese otro que se vuelve Todo o Nada (los extremos se tocan). En este sentido, es reveladora la frase final de la voz primera en Catálogo razonado, que anuncia la posibilidad de olvidar a la mujer o recordarla, disfrazarla para que reaparezca y que ella nunca sea real sino que sólo exista en la posibilidad de repetirse a sí misma como otra. La Mujer se desdobla, se multiplica y llega a ser definida como una pura contradicción. Presencia ubicua y omnipresente como la vida, es también — como la vida - contingente, paradojal, contradictoria, pero también como el Arte, al que podemos acercarnos como un oficio que debe dominarse o como un modo de expresarnos para luchar contra la contingencia y, dice García Ponce, "satisfacer nuestra necesidad de absoluto" (García Ponce 1997b: 48).

En general, los personajes de García Ponce son jóvenes o de espíritu juvenil: participan de lo que los hindúes llaman artha ("bienes materiales", "riqueza", "economía”) porque pueden satisfacer sus necesidades sin preocuparse, y desarrollan el kama ("placer" o "goce sensual"). La voluptuosidad es "para los corazones libres, algo inocente y libre, la felicidad del jardín terrenal” (Nietzsche 1983: 264).

Freud, sin embargo, no considera posible una vuelta a un estado de inocencia; para él, el instinto de muerte es la manifestación de una 
tendencia que nos impulsa a reproducir un estado anterior, a retornar al "paraíso" perdido. Dice Bruce-Novoa, en un ensayo sobre García Ponce: "no se puede regresar al jardín de la infancia, sino que más bien hay que encontrar otro espacio, con las mismas características, en la vida adulta" (Bruce-Novoa: 114). Los personajes vuelven constantemente al placer. Aun con el uso de su conciencia y de su razón - de ahí también el erotismo-, Inmaculada nunca dejó de ser la niña que, con Joaquina, jugaba en la casa de muñecas. Es una especie de infancia prolongada en la edad adulta, la búsqueda de ese placer, de ese estado de juego del que habla Schiller, de ese abandono -inocente en sí mismo- que permanece en el recuerdo y que la lleva a otros placeres.

Y si bien, en un sentido freudiano, Inmaculada y otros personajes son perversos, al no encontrar restricciones se mueven con naturalidad y libertad en un ámbito que les pertenece: en la intimidad son inocentes en términos evangélicos. Sólo la realidad exterior es capaz de anular o postergar el encadenamiento del deseo y sus avatares. Poco después de iniciada su relación con Gilberto, Paloma, en De anima (1984), llega a ponerse celosa de que su amante baile con otra en una fiesta y llega a confesar que con Armando, su ex esposo, fue con el único con quien llegó a sentirse culpable de mentir: con él no podía ser inocente. En la medida en que la mujer se aproxima a Gilberto, descubre otro tipo de relación: se percata de que éste pretende contemplarla en la plenitud de su ser y, por tanto, la culpabilidad y los celos se desvanecen.

Pero García Ponce no pretende persuadir al lector de que sea perverso polimorfo, sino, en todo caso, hacerlo cómplice de las utopías intimistas que crea. La prueba de ello es que no posee la necesidad de recurrir a los argumentos — sofísticos, según Klossowski- del Marqués de Sade. Sofísticos porque los discursos del perverso en Sade no salen de la razón normativa. El persuadido debe rechazar las normas de la comunidad conscientemente, mientras que el cómplice acata la perversión sin necesidad de argumentos. Como la narrativa de García Ponce es intimista, se halla, en cierto sentido, liberada de esa generalidad normal a la que Sade invoca para que su contra-generalidad implícita se haga monstruosidad integral o prostitución universal. Según el Diccionario de la Real Academia Española, en su versión de 1992, "perverso" es —en la acepción que nos interesa- el que corrompe las 
costumbres o el orden y estado habitual de las cosas. Pero los personajes de García Ponce, con la imaginación y la acción, crean y asumen su propio orden en la intimidad. Por tratarse de una obra intimista, el poder sobre el sexo no se transmite a partir de un discurso jurídico, pues éste es prácticamente inexistente al no regir el comportamiento sexual de los personajes, quienes no atentan contra el orden social exterior porque se trata de una literatura disociada, como ya lo hemos visto, de los aspectos sociales. Por ejemplo, el doctor Ballester en Inmaculada o los placeres de la inocencia (1989), aunque se considere un "falso doctor" porque en realidad le interesan los enfermos como tales (García Ponce 1995b: 190), no sólo tiene el cuidado de advertirle a Inmaculada que no comente dicha confesión, sino que también admite que "cura" a algunos pacientes. Jamás atenta contra el orden de su clínica. Todo lo contrario: cuando Arnulfo - perverso y auténtico "culpable" - introduce el desorden al "contratar" a Inmaculada como prostituta para los locos, Ballester no duda en despedirlo (García Ponce 1995b: 305).

Además, en García Ponce jamás encontramos ni el asesinato ni la tortura, y en eso coincide con Henry Miller: "todo ese sadismo perverso me horroriza. Siempre he dicho que mi literatura es saludable porque es gozosa y natural. Nunca digo nada que la gente no diga y haga todo el tiempo" (Miller, citado por Batis 1989: 71). Es más, la fuerza de Paloma en De anima "no se finca en la maldad. Paloma ni siquiera llega al brillo maligno que ostentan las uñas de la Roberte de Klossowsky; ni tampoco alcanza la estatura demoniaca de las hembras de Tanizaki” (Anhalt: 10). Recordemos que Roberte envenena a su marido. Lo que Anhalt dice de Paloma es aplicable a la mayoría de los demás personajes femeninos de García Ponce. La disponibilidad de ellos implica su propia voluntad de estar disponibles. Las pocas escenas de sadomasoquismo en Inmaculada... se dan porque la protagonista descubre ese placer del poder como una parte interior, oculta, y porque Rosenda y la misma Inmaculada lo aceptan mediante la palabra y la actitud; lo asumen como adultos, sin forzar a nadie. Después de que Inmaculada le pega a Rosenda, el pintor Ernesto Mercado les pega a las dos con el cinturón, pero les pide al final que hagan que Miguel y Tomás "no se den cuenta de los golpes" (García Ponce 1995b: 260), lo que implica una voluntad de no alterar el orden fuera de la propia intimidad y, sobre todo, la voluntad de tratar a las mujeres como a 
individuos al propugnar una complicidad mutua, ajena a la soledad del soberano personaje sadiano, quien, a decir de Bataille, no toma en cuenta a sus semejantes. Tanto Blanchot como Bataille coinciden en que Sade niega al prójimo, hace su obra en la soledad, en la extrema discontinuidad con el mundo y con el prójimo; su mensaje es la insignificancia del otro en la continuidad del crimen y de la crueldad (Bataille 1997: 232-233, 245, 262). También se debe tomar en cuenta que en el mundo sadiano, como lo ha advertido Roland Barthes, el libertino posee un rasgo que no comparte: la palabra, el habla. El que dispone del lenguaje es, pues, el amo, mientras que la víctima, el objeto, se calla; si no lo hace, sólo ofrece "voces mecánicas" (Klossowski, Barthes et al., 63). Esto no ocurre de ninguna manera en García Ponce, aunque, como en Sade, se conciba — por medio de la imaginación y el lenguaje- lo inconcebible (por ejemplo, Inmaculada), si bien la creación de utopías o de comportamientos inconcebibles es característica de toda literatura cuyo objetivo no es sólo la mímesis ni el "realismo".

En el discurso de García Ponce, ajeno a la moral, la razón emerge para controlar y limitar la violencia: impone o implica prohibiciones que hacen del juego algo placentero para todos, sin negar o victimar al otro con la crueldad. En Pasado presente, por ejemplo, Virginia le tiene mucho miedo a los golpes de Abelardo y aprende a evitarlos, pero también aprende, gracias a Catalina, el placer del acto lesbiánico (García Ponce 1995a: 197-198). En esta misma obra, Geneviève es manipulada "como si fuese un objeto", pero — y esto es lo importante- actuaba "de acuerdo no sólo con su placer, sino también con su temor al futuro" (García Ponce 1995: 333). En otras palabras, en García Ponce la razón no está puesta al servicio del horror sanguinario ni del uso del cuerpo con fines sádicos. Se trata, como afirma el moribundo del Diálogo entre un sacerdote y un moribundo de Sade — personaje excepcional en el corpus de esta obra- de producir la felicidad ajena y la propia. Para ello es necesario que la razón imponga límites. En García Ponce "las perversiones que no alteran las relaciones interpersonales son aceptadas, no así las que desmantelan grupos y producen algún tipo de conmoción social" (Gliemmo: 175). De hecho, en el terreno de la transgresión en general, Bataille aclara que ésta, al igual que la prohibición, está a menudo sujeta a reglas.

Pasión e inteligencia conforman la obra de García Ponce. Este movimiento dialéctico se advierte en sus personajes y, por ello, paralela a 
la inocencia, se encuentra su negación dialéctica: desde que hay inteligencia, raciocinio, saber, la inocencia se vuelve relativa: "En verdad nada era inocente, aunque tomara la forma de lo casual. Había una mal disimulada expectación en cada uno de ellos. Ninguno de los gestos de Geneviève dejaba de acentuar su natural sensualidad" (García Ponce 1995a: 333). Lo importante es que, como ya lo hemos advertido, y como lo advierte Eduardo en El libro, de esa malicia se retorna a la inocencia del placer en sí: sin culpa alguna.

Prosiguiendo con Sade, el erotismo se sitúa en el dominio de los individuos, mientras que el sadismo lo hace en el de las personas cosificadas. Para que exista el sujeto obediente debe haber un sujeto que legisla; pero la obediencia y la disponibilidad, si bien se hallan enlazadas, no son lo mismo. La voluntad de estar dispuesto a obedecer implica la existencia de alguien consciente de su voluntad y en una relación que puede ser de subordinación para con quien posee la voluntad de someter, o simplemente ser una relación de carácter lúdico, donde subsista la complicidad del mutuo acuerdo.

Se podrá argumentar que en Sade las acciones suelen también ocurrir en la intimidad y que, por tanto, no hay una real y efectiva alteración del orden social ni de la comunidad, por más pretensiones o persuasiones del "filósofo infame". Sin embargo, el que Sade adopte un discurso filosófico y moral e invoque a la naturaleza para mostrar y justificar las acciones de los verdugos, implica que su pretensión es convencer. Por otra parte, la comparación entre Sade y García Ponce “podría” establecerse en el orden erótico. Según Christopher Domínguez, el erotismo en García Ponce

es técnicamente sádico, una retórica más que una moral de la ambigüedad. Como Sade, García Ponce se complace en la repetición mecánica de los entuertos sexuales. Esa insistencia cansa al lector, pues es hija de un autor que sufre la recurrencia fatal de sus obsesiones (Domínguez 1997: 11).

La palabra "entuertos" implica someterse a un orden moral preestablecido, aunque prácticamente inexistente en la ficción de García Ponce. No se trata, como dice Nietzsche, de "calumniar el desear". Al colocar al deseo en un plano moral — Sade es, indiscutiblemente, un moralista al revés - se le calumnia. Advierte García Ponce que "La 
aspiración máxima de la moral, su meta, es la pureza absoluta. Y dentro de ella no existen los contrastes" (García Ponce 1968: 98), pero su aspiración —en sentido inverso- puede ser también la impureza absoluta, la prostitución universal y, entonces, tampoco acepta contrastes. Además, es sabido que todo autor tiene sus obsesiones, si bien en algunos — como en García Ponce- son mucho más recurrentes y marcadas. Domínguez califica a García Ponce como "sádico que vota por el Eterno Femenino" (12): su obsesión principal es, más que la "técnica" sádica, la mujer. Pero si Sade es un moralista al revés es porque para él existen las prosperidades del vicio (Juliette) o los infortunios de la virtud (Justine) y no, como en García Ponce, los placeres de la inocencia (Inmaculada). ${ }^{3}$ Nuevamente, García Ponce coincide con Henry Miller, quien exclama: “¡Cuán afortunado soy de que no se me acuse de pervertido o degenerado sino simplemente de ser alguien que hace el sexo placentero e inocente!" (citado por Batis 1989: 204). La dicotomía moral de Sade, que implica una conciencia moral y la transgresión consciente de las normas, no es explotada por García Ponce porque la propuesta de éste es —insistamos en ello- amoral como el arte. Dice Gilberto en De anima: "La belleza, como Paloma, no tiene moral” (García Ponce 1984: 109). Finalmente, tanto en Sade como en García Ponce encontramos un poder sobre el objeto erótico, pero en Sade este poder es ilimitado y va acompañado por una indiferencia hacia la suerte de la víctima, que se vuelve insignificante, cosa que jamás ocurre en García Ponce, principalmente porque no hay verdugos que reclamen la obediencia absoluta; ni siquiera hay víctimas en el sentido sadiano. Cuando Gilberto dice, evocando un poema de Lezama Lima: "Uno no puede sentir que nadie sea su mujer si está realmente enamorado de ella. 'Ah, que tú escapes...' Entonces sólo se puede tener a la mujer de otro. Ese es el verdadero signo de la perversidad" (García Ponce 1984: 34), se está indudablemente refiriendo a la desposesión. Muy contraria es la frialdad del perverso sádico, que no permite, en el juego de la voluntad, el intercambio libre del deseo, sino que se perfila y despliega únicamente hacia el círculo obsesivo, abs-

\footnotetext{
3 "El nombre de Inmaculada o los placeres de la inocencia — aclara García Ponce- es un deseo de plagiar a Sade cuando dice "Juliette o las prosperidades del vicio" o bien "Justine o los infortunios de la virtud". Sade usa con mala voluntad los infortunios de la virtud o las prosperidades del vicio. Yo, los placeres de la inocencia" (Aranda Luna 25).
} 
trayendo la inclinación sensual y su emotividad intensa y deseante. Por ello, aunque el orden de lo perverso no esté de ningún modo excluido, resulta simplista la reducción del mundo de García Ponce sólo a ese orden. Hay ciertamente un escape de la norma y la obsesión ceremonial, reiterativa —a veces fría — de los gestos, pero hay más: hay seducción y libertad, es decir, flexibilidad y no rigidez de la regla.

En la obra que nos ocupa hay un reinicio de la fuerza vital, por lo que no se da la aniquilación absoluta del objeto. Los personajes suelen elegir la vida, no como acto genésico, sino placentero, conducente a la petite mort - extática, atemporal en el instante en que se da, pues es la anulación de la duración calculada- en el círculo vicioso enmarcado por el mutuo placer. No suele existir la elección de muerte implicada en la categoría de Bataille lo imposible, como un vivir la libertad al borde de los límites, porque los personajes de García Ponce no suelen estar abocados a un destino trágico: no hay Orestes ni crueldades ni desórdenes ilimitados o excesivos: "sólo está ávido de lo imposible quien se dibuja un destino trágico” (Bataille 1979: 175). Lo imposible, sin embargo, se manifiesta en la obra de García Ponce como espacio literario y también como lo "imposible sexual” en tanto acto antigenésico (por ejemplo, en mujeres como Inmaculada, quienes, a pesar de su promiscuidad, nunca se embarazan), pero sin el aspecto terrible. La distancia entre las novelas de Sade o de Bataille y las de García Ponce puede ser la misma — toda proporción guardada - que la existente entre las películas de la Trilogía de la vida (El Decamerón, Los cuentos de Canterbury y Las mil y una noches) y Saló o los 120 días de Sodoma, todas de Pier Paolo Pasolini, aunque esta última basada justamente en Sade. Sobre Saló, afirma Baudrillard que se trata de una carencia de seducción, es decir, de lo femenino: se trata de un mundo masculino donde todo está muerto, donde no hay ni complicidad ni promiscuidad; el placer se dirige a su meta y encuentra a su objeto muerto. Lo masculino está más cerca de la ley; lo femenino, del goce (Baudrillard: 26-29). Las mil y una noches, en cambio, es la plena realización del amor, como ocurre en general en todas las literaturas orientales.

Ahora bien, si admitimos que "El vicio podría concebirse como el arte de darse, de una manera más o menos maníaca, el sentimiento de la transgresión” (Bataille 1997: 352), Sade, García Ponce y Bataille (en sus novelas) son "viciosos", obsesivos: lo que cambia es el tipo de representaciones, las intenciones y, en definitiva, los matices y la con- 
cepción, ya que el discurso de la transgresión no es unívoco ni aparece en todos de la misma manera. En García Ponce más bien se dan las "perversiones" que Herbert Marcuse califica de "compatibles con la normalidad en la alta civilización” (Marcuse: 211) porque no atentan contra ella: no son formas destructivas. Hay, en cambio, una reactivación de la sexualidad polimorfa: los personajes, aunque trabajen, adquieren, incluso en el trabajo, la satisfacción de sus necesidades.

Si me parece impertinente comparar (aunque no contrastar) al escritor yucateco con Sade es, sobre todo, porque en el primero aparece la amoral inocencia. En Sade, la inocencia es negativa y pasiva (Justine es atracción para el libertino), mientras que en García Ponce la inocencia (por ejemplo, Inmaculada) desempeña un papel positivo e incluso activo. En Sade la filosofía es voluntad de desunir, violentar. La inocencia en sus personajes no existe porque ellos son conscientes de que están transgrediendo un orden jurídico y social al someter a sus víctimas: son culpables. Afirma Octavio Paz, refiriéndose a García Ponce, que la palabra inocencia, asociada a la sexualidad

no es realmente un término moral ni científico sino religioso: la inocencia es una plenitud de ser, del mismo modo que el pecado es una falta. La inocencia es abundancia, el pecado es carencia. Lawrence lo sabía perfectamente $y$, al hablar de sus novelas, en una carta a un amigo, le dice que todas ellas giran en torno al enigma de la sexualidad " $y$ han sido escritas desde la profundidad de mi experiencia religiosa" (Paz 1996a: 383).

En las representaciones eróticas de García Ponce hay elementos religiosos — sin importar que sean o no heréticos desde la perspectiva cristiana-, una mística y una irrupción de lo sagrado y del misticismo. En este sentido, la aseveración de Domínguez resulta aún más parcial, pues, como afirma Paz, en la figura del libertino "no hay unión entre religión y erotismo" (Paz 1996b: 222), aunque su actitud pueda convertirse, por efecto de la pasión, en una religión al revés. En los "monstruos" de Sade, sin embargo, no hay éxtasis, sino, en todo caso, frenesí, o un "éxtasis" del pensamiento en la representación del acto reiterado a "sangre fría", "éxtasis — dice Klossowski- opuesto aquí a su análogo funcional: el orgasmo" (Klossowski, Barthes, et al.: 34); tampoco existe la plenitud en el sentido que le confiere Paz, plenitud e inocencia que, en cambio, se hacen explícitas incluso en la solitaria 
Claudia, de La cabaña (1969), que llega a sentir su cuerpo como una prolongación de su deseo y a la posibilidad de inocencia como un elemento de ese deseo, aunque carezca de objeto; que se reconoce "dueña de una limpia inocencia" y está llena de sí, aunque sin saber a dónde dirigir esa plenitud (García Ponce 1982c: 40, 62, 71, 74, 94, 97). La obra de García Ponce abunda en estos temas, pero, en general, sin el elemento de la soledad que yace en La cabaña.

Por lo anterior, cuando Barthes asume que el dolor en Sade es nietzscheano, es decir, inocente — una desdicha inocente, un rechazo de la Falta - y compara la inocencia del enamorado con la de los héroes de Sade (Barthes: 137), no toma en cuenta el desplazamiento amoral de la pasión amorosa ni la excesiva moralidad transvaloradora que se opera en la conciencia del héroe sadiano, si entendemos por héroe el personaje que porta los valores explícita o implícitamente aceptados como positivos por el autor dentro del contexto de la obra (y no por el lector). En García Ponce prevalece la amoralidad y la asistematicidad en cuanto a la reflexión: las cosas representadas, ajenas generalmente a un discurso de la crueldad, simplemente son. De hecho, a García Ponce Sade le parece profundamente aburrido, entre otras cosas, "por filósofo pesado", de tal modo que prefiere "leer interpretaciones de Sade que a Sade" (Driben / Legrand: 11). Tal asistematicidad moral y filosófica, ajena a un "filósofo pesado", es notoria en el manejo de la ambigüedad inocencia-perversidad en la obra de García Ponce. Por ejemplo, al final de La cabaña, Claudia no sabía "si hacía bien o mal" (1982c: 181). En el libertinaje de Sade hay un conocimiento axiológico y una reflexión que lo invierte, hay un poder sin límites sobre el objeto sexual, hay una víctima y un victimario, y suele ser este último el héroe. Hay, por tanto, una relación destructiva. La única complicidad existe entre los verdugos. En García Ponce es notoria la entrega, la complicidad con el otro, la alegre aceptación; por ello no existen las víctimas ni los victimarios en la intimidad, sino una voluntad de estar dispuesto porque todos son cómplices inocentes en su perversidad. La mujer en García Ponce nunca es víctima. Dice Paloma: "Si no tiene miedo de serlo, una mujer debe eliminar todos los obstáculos que impiden que los demás la vean como ella quiere que la vean" (García Ponce 1984: 25. Cursivas mías). Más que con Sade, García Ponce coincide a todas luces con Henry Miller, para quien "el artista está obsesionado por el pensamiento de recrear el mundo, con 
el fin de restaurar la inocencia del hombre. Además sabe que el hombre sólo puede recuperar la inocencia si recobra su libertad" (citado en Batis 1989: 101), libertad implícita en las palabras de Paloma, quien la vive a través de búsquedas y encuentros. Para el autor yucateco, "el arte es una búsqueda de la inocencia” (García Ponce 1997b: 51), con la cual "no hay que enfrentar al mundo, sino [...] vivirlo" (ibid.: 265). En definitiva, el camino que a García Ponce le interesa presentar, como él mismo lo afirmó, es "demostrar que el arte es siempre inocente", lo que significa que puede ser percibido sin inocencia y así hacerlo culpable: "no creo que haya algo tan perverso como la inocencia [...] Tengo 13 libros de ensayos basados en esa voluntad de acercarme a las obras de los demás con una mirada desprovista de inocencia y 13 novelas para afirmar la inocencia" (Aranda Luna: 25). Es ésta una de las ambigüedades fundamentales en la obra del autor, ambigüedad que se inicia con el mismo acto del lector-voyeur. Mi lectura - esta lectura- ciertamente no es inocente, como no lo son las lecturas de García Ponce, a pesar de que haga surgir esa inocencia, por ejemplo, al escribir sobre su experiencia al leer la poesía de Paz: el hecho de que en la inocencia que esta poesía nos muestra "reconocemos el principio sagrado de la vida y al hacerlo nuestras acciones recobran su sentido original, participan de la realidad de una manera natural" (García Ponce 1997b: 265).

En su ensayo "Literatura y pornografía", García Ponce apunta un rasgo esencial de la conducta del libertino en Sade: su necesidad de convertir al otro en objeto de placer sin voluntad individual, "cuyo propósito es proporcionar placer y nada más”, y aclara que tanto en el libertino como en su víctima "sólo la degradación de la calidad como persona permite que el libertinaje se cumpla" (García Ponce 1988: 111). La diferencia es que en la poética vitalista de García Ponce, la desintegración del sujeto y la objetivación del otro tiene como fin y fundamento "ser sólo el placer que das y que te dan" (García Ponce 1992, v. I: 25), lo que implica la inocente naturalidad de una reciprocidad hedonista (o un hedonismo recíproco), mientras que, a decir de Bataille, el extremo del vicio es precisamente lo opuesto al placer (Bataille 1979: 39). Es cierto, pues, que repentinamente todos los personajes del autor yucateco pueden convertirse en objetos, pero no para ser victimados: "Fuiste un objeto, Anselmo era un objeto, Mariana sabía cómo ser un objeto y no quería más que ser un objeto. No que- 
ría nada. Ella ya no era ella. Un olvido innombrable. Nadie es el objeto de nadie. Los objetos ni siquiera son de sí mismos" (García Ponce 1992, v. I: 25). Esta situación se halla indiscutiblemente en el ámbito de la inocencia en el sentido anotado por Paz. Mariana es descrita como "un ángel" y se le define como "la pureza" (ibid.: 21). Desde el momento en que no hay victimarios ni degradación o humillación, no hay culpables. Cuando surge un sentimiento de culpa, éste es ambiguo y se resuelve en la acción inocente de una transgresión en que la víctima es, en todo caso, el orden del trabajo, ya que es el principio de placer el que prevalece. Los personajes de García Ponce no pertenecen a la nobleza ociosa: su trabajo — cuando se explicita — les sirve para obtener el placer.

Si en Lady Chatterley's Lover es enaltecida la comunidad agrícola a la que se refieren Masters y Johnson (1976) como propicia para la sexualidad sana, es también cierto - y en esto el escritor urbano García Ponce coincide con D. H. Lawrence-, que aparece el adjetivo "inocente" como un atributo de Connie, que el narrador alude a la belleza que envuelve el "misterio fálico", que Connie se refiere al pene de Mellors como "inocente", que el rostro de éste — cuando se halla en una ocasión con Connie- es comparado por el narrador con el rostro de Buda: "motionless in physical abstraction", y que el acto amoroso entre Connie y Mellors es calificado como un "acto creativo, mucho más que procreativo" (Lawrence: 62, 163, 253, 255, 336), lo cual implica ya una transgresión del orden religioso judeocristiano y del orden del trabajo. Pero más interesante aún resulta la alusión a Abelardo y Eloísa: “EEl refinamiento de la pasión, las extravagancias de la sensualidad! Y necesaria, siempre necesaria para quemar las falsas vergüenzas y fundir el pesado mineral del cuerpo en la pureza. Con el fuego de la completa sensualidad" (Lawrence: 297-298). ${ }^{4}$ A propósito de esta novela, Lawrence expresa, en un ensayo, su deseo de que los seres humanos puedan pensar el sexo limpiamente (Lawrence: 12). De igual modo, en Trópico de capricornio, Miller dice que su pene "presentaba un aspecto tan inocente como siempre" (Miller: 84). ${ }^{5}$ La diferencia entre Lawrence, Miller y García Ponce es que el primero identifica —en sus ensayos- al sexo auténtico con la pasión por la fidelidad, contrapuesta a la prostitución,

\footnotetext{
4 "The refinements of passion, the extravagances of sensuality! And necessary, forever necessary, to burn out the false shames and smelt out the heaviest ore of the body into purity. With the fire of sheer sensuality".

5 "I looked at my cock and it looked just as innocent as ever".
} 
y asimismo propone al falo como el auténtico "puente hacia el futuro", mientras que Miller alude al "mundo ovárico": "The ovarian world is the product of a life rhythm" (Miller: 262). Pero los tres proponen la inocencia del sexo como tal.

Por el contrario, Sade, cuyos conceptos de virtud y vicio se hallan inscritos en la transvaloración racionalista de un sistema moral, es ajeno a esa experiencia. Él no desune para unir. En el Marqués, hay relaciones desesperadas: la búsqueda del placer por el placer (por ser parte de lo natural) conlleva un dolor extremo que suele desembocar en la anulación del otro como otro, en la intolerancia y no en la mutua aniquilación por medio del placer extático. En Crónica de la intervención, María Inés dice que "esperaba que José Ignacio me matara, mejor dicho me mataba cada vez que hacíamos el amor, era, es, ese mismo deseo de desaparición, de que me aniquilaran por completo para ser en el otro, para ser el otro, no pertenecerle, sino ser él", y agrega: "Ese deseo de aniquilación sólo es femenino. Al ser él, yo no voy a ser un hombre. Lo convierto en mujer" (García Ponce 1992, v. I: 167): he ahí la continuidad a la que se refiere Bataille y que se experimenta en el erotismo de los cuerpos, concretamente en el orgasmo, en la petite mort. No pertenecer al otro, sino ser el otro implica la unión sustancial en la experiencia extática (salir fuera de sí) inexistente en el sádico, quien siempre es él mismo y reafirma su discontinuidad en su libertad de anular al otro.

A pesar de la disponibilidad sexual de muchas figuras femeninas, las obras de García Ponce - y en particular sus grandes novelas y cuentos- no descansan en la simple pornografía, en la banal transgresión de las costumbres por el simple hecho de transgredirlas, en la frívola -aunque excitante- descripción de "perversiones". La voluntad del autor no reside, no se estanca en épater le bourgeois, en retar o provocar a la sociedad: "el arte, como el erotismo — dice el autor-, es una forma de inocencia. La provocación pertenece a la moral y si hablamos de arte, hablamos de un fenómeno estético en el que la moral no existe" (Cosmos: 33). Su obra no va dirigida a una sociedad establecida —ésas no son sus pretensiones-, lo cual sí sería provocación. Su obra va dirigida al individuo: "si pensamos en el lector privado, para él no hay nada prohibido, y por lo tanto, tampoco cabe hablar de provocación”, e insiste: "en el sueño, como en el erotismo, todos somos libres e inocentes" (ibid.: 33-34). A estas ideas hay que agregar que en sus personajes importantes no hay malicia ni conciencia de que están haciendo mal o trans- 
grediendo normas; en esto coincide, nuevamente, con Lawrence: "no merece la pena mantener el sucio deseo de épater le bourgeois, de desconcertar a la gente normal. Si utilizo palabras tabú, es por un motivo" (Lawrence: 43). Ese motivo obedece a la necesidad de un vocabulario para representar lo que él considera armonía entre sexo y pensamiento: "Debemos aceptar la palabra culo del mismo modo que aceptamos la palabra cara, puesto que culos tenemos y tendremos siempre" (ibid.: 90), dice en otro ensayo.

La insistencia en la "pureza" e "inocencia" de las protagonistas más importantes de las obras de García Ponce - Mariana, Paloma, Inmaculada...- es el símbolo de la falta de culpa en sus actos. Esto constituye una verdadera y auténtica obsesión. De Geneviève se dice: "Tan inocente, tan sensual. Era la pureza misma” (García Ponce 1995a: 332). Entonces los personajes principales se mueven dentro de lo que Nietzsche califica de "extramoral", en cuanto a que el valor de sus acciones no reside específicamente en sus intenciones (Nietzsche 1996: 58-59). De tal modo, reaparece la inocencia tal como la afirma Nietzsche en $A s i$ habló Zaratustra: "Más allá del bien y del mal está tu reino. Tu inocencia está en no saber lo que es inocencia" (Nietzsche 1983: 415. Cursivas mías). Y si Bataille considera a Nietzsche como filósofo del mal, lo hace en tanto que la pretensión de éste radica en transvalorar los valores. Bataille, en efecto, califica al mal como "turbia ruptura de un tabú" producida por y desde el ejercicio de la libertad (Bataille 1989: 17). Él mismo cita las siguientes palabras de Nietzsche: "Sería espantoso creer aún en el pecado; por el contrario, todo lo que hacemos, aunque debiésemos repetirlo un millar de veces, es inocente" (ibid.: 51).

Literalmente, en la superficie de ciertas acciones, hemos detectado la transgresión, pero también —en el caso de María Inés - la toma de conciencia a posteriori de la unión extática con el otro. Lo interesante es que en la apariencia esto es lo no-intencionado, el valor decisivo de las acciones, según la psicología nietzschiana, para la que, finalmente "Lo que se hace por amor acontece siempre más allá del bien y del mal" (Nietzsche 1996: 107). En la gran novela de Musil, Ulrich sostiene que es el hombre quien le da carácter a la acción y no viceversa, pues tanto el bien como el mal en realidad forman un todo (Musil 1952: 749) ${ }^{6}$.

\footnotetext{
6 "Der Mensch gibt der Tat den Charakter, und nicht umgekehrt geschieht es! Wird trennen Gut und Bös, aber in uns wissen wir, dass sie ein Ganzes sind”. Cfr. también El hombre sin atributos, vol. III, p. 90.
} 
Otro autor ateo, Bertrand Russell, se refiere a una neutralidad ética en cuanto a la contemplación y no específicamente en la acción. Para él una contemplación imparcial, es decir, exenta de la preocupación por el yo, "no juzgará buenas o malas las cosas", aunque pueda haber un sentimiento de amor o de bondad. Russell proclama la neutralidad ética como un olvido del bien y del mal para pensar y conocer sólo los hechos, con lo cual, según él, será más factible lograr el bien de lo que lo es o sería para quienes desfiguran los hechos con sus deseos (Russell: 39, 41-42). La actitud extramoral, en Nietzsche y Musil, y la neutralidad ética, en Russell —aunadas al concepto de "indiferencia moral" de la forma, en Thomas Mann, o de "inocencia" del arte, en García Ponce- sugieren que no sólo las acciones, sino también el hecho de pensarlas gracias a la contemplación, al acto voyeurista, se sitúan en sí más allá del bien y del mal. García Ponce lo expresa en estos términos: "No creo que haya una división tan radical entre el bien y el mal. Ni siquiera creo que el pensamiento conduzca a ningún lado más que al mismo hecho de pensar" (Anhalt: 61).

Al principio de este ensayo, afirmé que García Ponce apuesta por un vitalismo energético y positivo, y creo que tal aseveración - a pesar de algunas escenas violentas y de cierto pesimismo en Crónica de la intervención y en La invitación - ha quedado probada. No obstante, ¿ha sido esta visión de continuidad vitalista inherente a la totalidad de la obra de este autor? Él mismo advierte un cambio en su visión del mundo. Los relatos de La noche (1963) "están animados por una visión del mundo que puede y debe considerarse negativa" (García Ponce 1989: 44). En efecto, ni el final de los tres relatos es "feliz" ni hay solución a los conflictos. Los temas son la muerte, el suicidio (en "Amelia"), la separación de los amantes (en "Tajimara") y la locura (en "La noche"). Según García Ponce, a partir de sus siguientes obras, sin abandonar sus preocupaciones, se ofrece "otra visión del mundo", y poco a poco llegará a la convicción de que el oficio de escritor "debe aplicarse a mostrar la bondad de formas de vida condenadas por la sociedad, por la moral [...] Mis obras recientes se apartan de La noche en este sentido" (ibid. Cursivas mías).

Es esa bondad, ese impulso vital que sus personajes principales demuestran haciendo visible - al desplegar sus deseos- que ciertas conductas sexuales no son nocivas para nadie, el que marcará sus relaciones políticas, así como la idea de comunidad amigable, desinhibi- 
da, que el autor privilegia. Se cumple en García Ponce lo que Bovero califica de política como "composición": la paz.

\section{BibLIOGRAFíA}

Albarrán Claudia y Adriana Gutiérrez. "La literatura como necesidad sin fin" (entrevista a Juan García Ponce ). En Universidad de México. México: octubre de 1991. 14-16.

Anhalt, Nedda G. "De anima, de Juan García Ponce / II. Todo igual, pero diferente”. En Suplemento Sábado, de Unomásuno. México, 21 de julio de 1984. 10.

Anónimo. El Rig Veda. Trad. del sánscrito y estudio de Juan Miguel de Mora, con la colaboración de Ludwika Jarocka. México: Centro Nacional para la Cultura y las Artes, 1989.

Aranda Luna, Javier. "La literatura siempre es un plagio: García Ponce". En La Jornada. México, 21 de mayo de 1989. 25-26.

Aristóteles. Política. Trad. Antonio Gómez Robledo. México: Porrúa, 1981.

Asa, María. "La realidad oculta otra realidad". En Suplemento Sábado, de Unomásuno. México, 25 de febrero de 1978. 4-5.

Barthes, Roland. Fragmentos de un discurso amoroso. Trad. Eduardo Molina. México: Siglo XXI, 1996.

Bataille, Georges. El erotismo. Trad. Antoni Vicens. México: Tusquets, 1997.

- Lo imposible. Trad. Margo Glantz. México: Premià, 1979.

- Sobre Nietzsche. Voluntad de suerte. Trad. F. Savater. México: Taurus, 1989.

Batis, Huberto. Lo que Cuadernos del Viento nos dejó. México: Diógenes, 1984.

- Estética de lo obsceno. México: Universidad Autónoma del Estado de México, 1989.

Baudrillard, Jean. De la seducción. Trad. Elena Benarroch. México: REI, 1990.

Bovero, M. "Lugares clásicos y perspectivas contemporáneas sobre política y poder”. En Bobbio / Bovero: Fundamentos del poder político. México: Grijalbo, 1985.

Bruce-Novoa, Juan. "Los cuentos de Juan García Ponce. Primera época”. En Armando Pereira (selección y prólogo). La escritura cómplice. Juan García Ponce ante la crítica. México: Era / Universidad Nacional Autónoma de México, 1997. 
Cosmos, Ángel. "Conversación con Juan García Ponce. La inocencia del erotismo". En Blanco Móvil, 41. México, enero-febrero, 1990. 29-34.

Domínguez Michael, Christopher. "Prólogo" a los Cuentos completos de Juan García Ponce. México: Seix Barral, 1997.

Driben, Leila y Dominique Legrand. "Juan García Ponce: 'Soy la tautología viviente”. En Sábado, de Unomásuno. México, 8 de mayo de 1982. $10-11$.

Espinosa, Jorge Luis. "El premio Juan Rulfo para Juan García Ponce” (entrevista). En Milenio. Sección Cultura. México, 24 de julio de 2001. 45.

Flores Aguilar, Verónica. "El goce de rozar los límites". Entrevista a Juan García Ponce. En Suplemento El Gallo Ilustrado, de El Día. México, 3 de noviembre de 1996. 6-8.

García Ponce, Juan. Juan García Ponce. Prólogo de Emmanuel Carballo. México: Empresas Editoriales, 1966.

- Desconsideraciones. México: Joaquín Mortiz, 1968.

- Teología y pornografía. Pierre Klossowski en su obra. México: Era, 1975.

- Las huellas de la voz. México: Ediciones Coma, 1982a.

- Catálogo razonado. México: Premià, 1982b.

- La cabaña. Barcelona: Montesinos, 1982c.

- De anima. México: Montesinos, 1984.

- Imágenes y visiones. México: Vuelta, 1988.

- "El autor y su obra: La noche". En Textual. México, agosto de 1989. 42-44.

- Crónica de la intervención (dos vols.). Lecturas Mexicanas. México: Centro Nacional para la Cultura y las Artes, 1992.

- Pasado presente. México: Fondo de Cultura Económica, 1995a.

- Inmaculada o los placeres de la inocencia. México: Fondo de Cultura Económica, 1995b.

- Novelas breves. Prólogo de Hernán Lara Zavala. México: Alfaguara, 1996.

- Cuentos completos. Prólogo de Christopher Domínguez Michael México: Seix Barral, 1997a.

- Cruce de caminos. Segunda edición. México: Universidad Veracruzana, $1997 \mathrm{~b}$.

Gliemmo, Graciela. "Crónica de la intervención: el desnudo de una escritura”. En Armando Pereira (selección y prólogo). La escritura cómplice. Juan García Ponce ante la crítica. México: Era / Universidad Nacional Autónoma de México, 1997.

Hahn, Dorothea. "La nueva novela de Juan García Ponce, voyeur de almas, será presentada hoy”. En Unomásuno. México, 18 de mayo de 1984. 15. 
Klossowski, Barthes, et al: El pensamiento de Sade. Trad. Manuel Lamana. Buenos Aires: Paidós, s/f.

Lawrence, D.H. Lady Chatterley's Lover. New York: Greenwich House, 1983.

- Sexo y literatura. Trad. Francisco Cusó. México: Distribuciones Fontamara, 1989.

Levinas, E. Totalidad e infinito. Trad. Daniel E. Guillot. Salamanca: Sígueme, 1977.

Marcuse, Herbert. Eros y civilización. Trad. J. García Ponce. México: Planeta, 1986.

Masters, William y Virginia Johnson. Crítica a las formas de sexualidad burguesa. Entrevista de Playboy, mayo 1968. Buenos Aires: Casa Editorial Cuervo, 1976.

Miller, Henry. Tropic of Capricorn. Introd. de Robert Nye. Londres: Flamingo. Harper Collins Publ., 1993.

Musit, Robert. Der Mann ohne Eigenschaften. Hamburg: Rowohlt Verlag, 1952.

- El hombre sin atributos, vol. III. Trad. F. Formosa. Barcelona: SeixBarral, 1973.

Nietzsche, F. Así habló Zaratustra. Trad. A. Sánchez Pascual. Madrid: Alianza, 1983.

- Más allá del bien y del mal. Trad. A. Sánchez Pascual. México: Alianza, 1996.

Paz, Octavio. "Encuentros de Juan García Ponce". En Obras completas, vol. 4. Generaciones y semblanzas. Dominio mexicano. México: Círculo de Lectores / Fondo de Cultura Económica, 1996a.

- Obras completas, 10: Ideas y costumbres, II. Usos y símbolos. México: Círculo de Lectores / Fondo de Cultura Económica, 1996b.

Pellicer, Juan. El placer de la ironía. Leyendo a García Ponce. México: Universidad Nacional Autónoma de México, 1999.

PoniatowsKa, Elena. "El escritor no existe, existen sus libros" (entrevista a Juan García Ponce). En Novedades. México, 25 de febrero de 1971. 9.

Real Academia Española. Diccionario. Madrid: Espasa Calpe, 1992.

Rosado, Juan Antonio. El engaño colorido. México: Universidad de la Ciudad de México, 2003.

Russell, Bertrand. Misticismo y lógica. Trad. Rovira Armengol. Buenos Aires: Paidós, 1975.

Sade, Marqués De. Diálogo entre un sacerdote y un moribundo. Prólogo de Maurice Heine. Trad. y notas de Mario Pellegrini. Barcelona: Argonauta, 1980.

Vallarino, Roberto. "Soy un autor de lugares privados, de interiores: Juan García Ponce”. En Sábado, de Unomásuno. México, 23 de diciembre de 1989. 1, 3-4. 